\begin{tabular}{lcc}
\hline UAD & ADJES (Ahmad Dahlan Journal of English Studies) \\
VoL. 8, No. 2, 164-178 \\
$\begin{array}{l}\text { Universitas } \\
\text { Ahmad Dahlan }\end{array}$ \\
https://doi.org/10.26555/adjes.v8i2.19956
\end{tabular}

\title{
Investigating Aspects Affecting Joe Biden's Speech on the Inauguration of the 46th President of The United States: A Political Discourse Analysis
}

\author{
1Yunika Triana*, 2Dewi Zulaiha \\ Email : ${ }^{1}$ zunikaaa@gmail.com, ${ }^{2}$ ewizulaiha.2019@students.uny.ac.id \\ ${ }^{1}$ Institut Agama Islam Negeri Surakarta \\ ${ }^{2}$ Universitas Negri Yogyakarta \\ *corresponding author
}

\section{ARTICLE INFO}

Article history

Received: 9 February 2021 Revised: 27 February 2021 Accepted: 11 July 2021

\section{Keywords}

political discourse analysis interpretation speech act

\section{ABSTRACT}

This paper aims to discover the aspects behind the politic historical events of Joe Biden's state speech. The speech, of course, has close relation with some of the historic American events that had just occurred. The research uses political discourse analysis to find the points uttered by the president who was influenced by ideology, status, and various socio-political contexts. At the inauguration on January 21, 2021, President Joe Biden's first national address is interesting to review. He conveyed messages explicitly to American society, but he also conveyed messages implicitly to political opponents. Researchers found some factors why messages spoken by Joe Biden including addressee, contextual situation, the intention of the utterance, speech act, and verbal act. These are the concerns by researchers as to whom the speech was delivered. It is not only aimed at directing the American society; it was also directed at his political rivals.

This is an open access article under the CC-BY-SA license.

\section{(2) (1) ( $)$}

\section{INTRODUCTION}

Since the early 20th century, research on the correlation between culture and language has existed. People find out the intention and purpose of a speaker in a particular context. For example, in the case of suicide, a victim leaves a final message; it is almost possible to know the cause of death and the final request to the family (Triana et al., 2020). This is just the beginning of the discourse. The process is the study of the relationship between language and social contexts. In a political context, the hearer will face many considerations in understanding a statement. In a political speech, the speaker chooses language features to persuade the hearer, influencing the audience's perceptions and building a good self-identity. It is a politician's way of taking political action to win the sympathy of all those who hear (Kameswari \& Mamidi, 2018). The recognition is a form of inseparable aspects between language and socio-political context. In addition, we need to understand that the culture and cognition of related people also influence the understanding of 
language in a political context. It is caused a political discourse analysis requiring evidence, authority, and truth (Dunmire, 2018).

The political situation in the United States has always been exciting to discuss because it is a powerful country that can influence situations in other countries. Recent journals confirmed that nations' power could be measured by paying attention to economic conditions, military power, political situation, international cooperation, state-building, trade, policymakers, democratization, and nuclear facility (Beckley, 2018). Moreover, politics always presents uncertainty and cannot be expressed normally (Austin, 2011). Since winning the 2016 election, Donald Trump has been in the center of international attention because of his political policies and controversy (Rachman et al., 2017). What is happening now also relates to the elections that have just been held in America, but Trump lost to his rival, Joe Biden. Joe Biden is the 44th vice president of the United States, Barack Obama. Now Joe Biden is a rising star who can beat his opponent, Donald Trump.

In a 2015 study on Joe Biden's personality, research suggested that senior politicians who have been in politics for too long can reduce the attractiveness of overuse of rhetoric. (Waisanen $\&$ Becker, 2015). This was caused Biden's great rhetoric ability shown in the media. The researcher believed that Biden's rhetoric is as bad as some of the other presidential candidates. In 2020, research revealed the results of Biden's political personality, which stated that Biden was a person who could be categorized as conciliatory and accommodating (Immelman, 2020). Biden was claimed be able to show the style of the president. The personality could be a good value against Donald Trump in the 2020 presidential election.

In his first official address, an elected president usually promises to do something. This speech is Biden's first political step as the executive board of government to do something new in the government. Moreover, America is the largest country globally; thereby, a US president certainly has tremendous political power. What was conveyed was, of course closely related to his political promises and his campaign vision. In the current research, the researcher tries to find out the background of what Biden said in his state speech, focusing on five essential aspects of people speaking. (Leech, 1983). These aspects can be identified through discourse analysis. In this case, political discourse can be used to see the relationship between language and the political context (Fairclough, 2013).

\section{METHOD}

The research was conducted using a qualitative method by investigating aspects behind Joe Biden's speech. Firstly, the data were taken from official YouTube of White House channel and identified using Political Discourse Analysis (PDA). It is 
https://www.youtube.com/watch?v=q5iCPKDp4V4, while the speech is the primary concept or the object of the research and Joe Biden is the subject of the research. Secondly, the researcher used narrative design to explore the findings that might have relation to the grand theory of pragmatics using political discourse analysis. Political discourse analysis is also critical discourse analysis that is used to seek individual ideas in the political context (Wall et al., 2015). Furthermore, PDA is an advanced analysis of critical discourse analysis (CDA), but PDA uses political context to break down the ambiguous statements of speakers (Van Dijk, 1997). The political context in the speech is also the primary item to explain the finding. It could be from a journal, news, or authentic reading related to the speech and the subject of the research. The research focused on analyzing the factors who is speaking, what it is about, where and when it is set, why he is speaking, and how the speaker says (Leech, 1983). Thus, only particular selected sentences of speech which were related to the aspects were presented to discuss. Practically, socio-political context and language feature that was used by the president, Joe Biden were explained to find the aspects. Particular aspects were classified based on Austin's theory of act which explained intention based on locutionary and illocutionary acts, and other aspects were classified by seeing the political phenomenon.

\section{FINDINGS AND DISCUSSION}

It is important to understand that that speech always has purposes. There are five aspects that show someone using pragmatics. The following aspects reflect a speaker's intention to be a hearer in the political context in the United States after Joe Biden's victory. These aspects appear to be marked out of the following particular utterances.

\section{Addressers and Addressees}

Biden's official statement at the inauguration ceremony presented Biden as a speaker, and the word "fellow American" represented the American people. In addition, based on the video, the researchers found that several elements of society attended the inauguration, including the 45th former vice president, Mike Pence and other former leaders besides Donald Trump, Biden's rival in the election. At the beginning of the opening of the statement, Biden paid special respects to the leader of the house Democratic Caucus, Nancy Peloci and others.

In Table 1, the statement submitted by the addresser / speaker reveals to whom the message was sent. American people are aimed at citizens of the country. Calling colleagues, member of the House representative and the senate indicate members of the official political institutions of the United States. Word predecessors indicate the former leader who came and participated in the inauguration. He also called world community leaders by stating the world. 
Table.1 UtTERANCE RELATED to AdDRESSER AND ADDRESSEE

\begin{tabular}{|l|l|l|}
\hline \multicolumn{1}{|c|}{ Addresser/Speaker } & \multicolumn{1}{|c|}{ Addressee/Hearer } & \multicolumn{1}{c|}{ Utterance } \\
\hline \multirow{5}{*}{ Joe Biden } & American people & My fellow Americans \\
\cline { 2 - 3 } & House of representative & $\begin{array}{l}\text { Speaker Pelocy... } \\
\text {..my colleagues I serve with in the house.... }\end{array}$ \\
\cline { 2 - 3 } & Senate & $\ldots$ and the senate up here \\
\cline { 2 - 3 } & Former leaders & $\begin{array}{l}\text {...we must be I thank my predecessors of both } \\
\text { parties for their presence here today }\end{array}$ \\
\cline { 2 - 3 } & World community & ... the world is watching watching all of us \\
\cline { 2 - 3 } & Biden' political opponents & It is none, but it is spoken implicitly. \\
\hline
\end{tabular}

\section{The context of the speaker}

The power of a president is closely related to the political situation. However, the politics of a president cannot be separated from all domains of life. In this case, Joe Biden was able to influence the political situation in the US and the world. Below are Biden's statements that are broadly related to a specific context.

Table.2 UtTERAnCE RELATED Particular CONTEXT

\begin{tabular}{|c|c|}
\hline Context About & Utterance \\
\hline Health & $\begin{array}{l}\text { we can reward reward work and rebuild the middle class and make health care secure } \\
\text { for all }\end{array}$ \\
\hline Education & we can teach our children in safe schools. \\
\hline Social & $\begin{array}{l}\text { This is a time of testing we face an attack under democracy and on truth a raging virus } \\
\text { growing inequity the sting of systemic racism a climate in crisis. }\end{array}$ \\
\hline Politics & $\begin{array}{l}\text {... and now a rise of political extremism white supremacy domestic terrorism that we } \\
\text { must confront and we will defeat. }\end{array}$ \\
\hline Culture & $\begin{array}{l}\text { Politics doesn't have to be a raging fire destroying everything in his path every } \\
\text { disagreement doesn't have to be a cause for total war and we must reject the culture in } \\
\text { which facts themselves are manipulated and even manufactured. }\end{array}$ \\
\hline Economy & $\begin{array}{l}\text { We face anger resentment and hatred extremism lawlessness violence disease } \\
\text { joblessness and hopelessness with unity. }\end{array}$ \\
\hline
\end{tabular}

The above statements are Biden's statement which implicitly talks about the US sociological environment. All aspects related to the power of the leader were put forward by the president. It indicates that the political context in government is not narrowly discussing political discourse but also about all aspects of politics, including economy, health, education, and culture.

\section{The goal of the speaker}

A person intends to convey an idea in his speech. The purpose is normative and pragmatic, but specifically addressed to certain people or groups. The following utterances indicate the purpose of speaker. 
Table.3 UTtERANCE RELATED TO PARTICULAR GOAL

\begin{tabular}{|c|c|}
\hline Goals & Utterance \\
\hline \multirow[t]{3}{*}{ To stop uncivil war in the US } & $\begin{array}{l}\text { We must end this uncivil war that pits red against blue, rural versus } \\
\text { urban, conservative versus liberal," Biden said. "We can do this if we } \\
\text { open our souls instead of hardening our hearts, if we show a little } \\
\text { tolerance and humility, and if we're willing to stand in the other person's } \\
\text { shoes - as my mom would say, 'Just for a moment, stand in their shoes. }\end{array}$ \\
\hline & We face an attack on our democracy and on the truth \\
\hline & $\begin{array}{l}\text { We must reject the culture in which facts themselves are manipulated } \\
\text { and even manufactured." Also, "There is truth and there are lies - lies } \\
\text { told for power and for profit. }\end{array}$ \\
\hline \multirow[t]{2}{*}{ 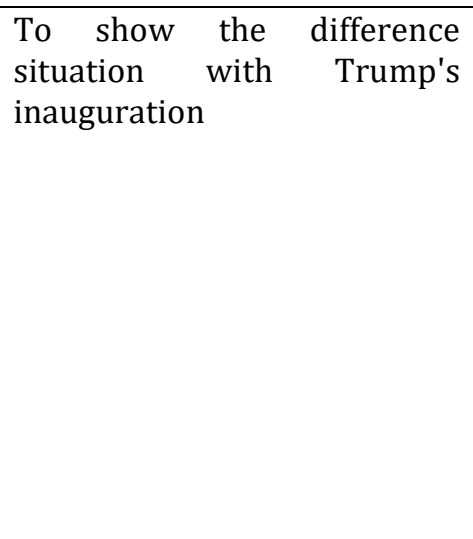 } & $\begin{array}{l}\text { Here we stand just days after a riotous mob thought they could use } \\
\text { violence to silence the will of the people, to stop the work of our } \\
\text { democracy, to drive us from this sacred ground," Biden said. "It did not } \\
\text { happen. It will never happen. Not today, not tomorrow, not ever. Not } \\
\text { ever. }\end{array}$ \\
\hline & $\begin{array}{l}\text { Together we shall write an American story of hope, not fear. Of unity, not } \\
\text { division. Of light, not darkness," Biden also said. "A story of decency and } \\
\text { dignity, love and healing, greatness and goodness. May this be the story } \\
\text { that guides us, the story that inspires us and the story that tells ages yet } \\
\text { to come that we answered the call of history; we met the moment; } \\
\text { democracy and hope, truth and justice did not die on our watch but } \\
\text { thrived; that America secured liberty at home and stood once again as a } \\
\text { beacon to the world. }\end{array}$ \\
\hline $\begin{array}{l}\text { To ask people to face the crisis } \\
\text { with courage }\end{array}$ & $\begin{array}{l}\text { Now we're going to be tested... } \\
\text { Are we going to step up? All of us? It's time for boldness, for there is so } \\
\text { much to do. And this is certain: I promise you, we will be judged, you and } \\
\text { I, by how we resolve these cascading crises of our era. Will we rise to the } \\
\text { occasion, is the question. Will we master this rare and difficult hour? }\end{array}$ \\
\hline To message to alliances & $\begin{array}{l}\text { So here's my message to those beyond our borders: America has been } \\
\text { tested, and we've come out stronger for it," Biden said, building on } \\
\text { themes addressed above. "We will repair our alliances and engage with } \\
\text { the world once again - not to meet yesterday's challenges, but today's } \\
\text { and tomorrow's challenges. } \\
\text { he also added: "And we'll lead, not merely by the example of our power, } \\
\text { but by the power of our example. We'll be a strong and trusted partner } \\
\text { for peace, progress and security. }\end{array}$ \\
\hline
\end{tabular}

The findings above tell us that Biden aims to give messages to American and other countries. He wanted to reform the recent US political condition and to assess international cooperation. Biden also insults political opponents by using opposing sentences and phrases. Biden's statement alluding to the events at the Capitol building, indicating resistance to political opponents. Moreover, Biden's words, "We must reject the culture in which facts themselves are manipulated and even manufactured." Also, "There is truth and there are lies - lies told for power and for profit" signifies the reform of everything under the power of the president for the truth.

\section{Speech act}

The speech deals with speech acts. These do not only deal with grammatical meaning, but also verbal acts in a particular situation. These intentions are the actual goal of the speaker. Then, 
the intentions of the speaker are also presented by interpreting the utterances on the following illocutionary acts column.

Table.4 UtTERAnCE Related to SPEech Acts

\begin{tabular}{|c|c|c|}
\hline Types of Acts & locutionary Acts & Illocutionary Acts \\
\hline Assertive & $\begin{array}{l}\text { in another January on New Year's Day in } 1863 \\
\text { Abraham Lincoln signed the emancipation } \\
\text { proclamation. When he put pen to paper the president } \\
\text { said and I quote ifmy name evergoes down into history. } \\
\text { It'll be for this act and my whole soul is in it, my whole } \\
\text { soul was in it today. }\end{array}$ & $\begin{array}{l}\text { Biden claimed that his soul } \\
\text { like what Abraham Lincoln } \\
\text { did in } 1863 .\end{array}$ \\
\hline Directives & $\begin{array}{l}\text {... and I ask every American to join me in this cause } \\
\text { uniting to fight the foes we face anger resentment and } \\
\text { hatred extremism lawlessness violence disease } \\
\text { joblessness and hopelessness. }\end{array}$ & $\begin{array}{l}\text { Biden directly asks all people } \\
\text { of Americans to fight } \\
\text { inequity. }\end{array}$ \\
\hline Commissive & $\begin{array}{l}\text { A cry for racial justice some } 400 \text { years in the making } \\
\text { moves us the dream of justice for all will be deferred no } \\
\text { longer a cry for survival comes from planet itself } \\
\text {... r rise of political extremism white supremacy } \\
\text { domestic terrorism that we must confront and we will } \\
\text { defeat... } \\
\text { My fellow Americans view the future most fear and } \\
\text { trepidation I understand they worry about their jobs I } \\
\text { understand like my dad they lay a bed staring at the } \\
\text { night staring at the ceiling wondering can I keep my } \\
\text { health care can I pay my mortgage thinking about their } \\
\text { families about what comes next I promise you I get it. } \\
\text { I pledge this to you I will be a president for all } \\
\text { Americans all Americans and I promise you I will fight } \\
\text { as hard for those who did not support me as for those } \\
\text { who did many centuries ago. }\end{array}$ & $\begin{array}{l}\text { Biden commit to reform } \\
\text { racial justice and law } \\
\text { supremacy. He also } \\
\text { convinces Americans to } \\
\text { believe that Mr. President } \\
\text { works in a best way. }\end{array}$ \\
\hline Expressive & $\begin{array}{l}\text { I thank my predecessors of both parties for their } \\
\text { presence here today I thank them from the bottom of } \\
\text { my heart. } \\
\text {...on this January day, my whole soul is in this bringing } \\
\text { America together uniting our people united in our } \\
\text { nation... } \\
\text {...with unity we can do great things important things. } \\
\text { recent weeks and months have taught us a painful } \\
\text { lesson there is truth and there are lies lies toll for power } \\
\text { and for profit and each of us has a duty and a } \\
\text { responsibility as citizens as Americans and especially as } \\
\text { leaders who have pledged to honor our constitution } \\
\text { and protect our nation to defend the truth and defeat } \\
\text { the lies. }\end{array}$ & $\begin{array}{l}\text { Biden expresses gratitude to } \\
\text { predecessors and he fells his } \\
\text { power can unite all element } \\
\text { of society. }\end{array}$ \\
\hline Declaratives & $\begin{array}{l}\text { We must meet this moment as the united } \\
\text { states of America if we do that I guarantee you we will } \\
\text { not fail we have never ever ever ever failed in America }\end{array}$ & $\begin{array}{l}\text { Biden declares that his effort } \\
\text { to bring America great again } \\
\text { will not fail. }\end{array}$ \\
\hline
\end{tabular}

The statement above indicates that Mr. President used all of the types of illocutionary acts. By bringing recent political conditions into America, he was convinced that he could fix all of his suffering. Based on the findings above, Biden tends to emphasize commissive act to convince people of Americans. cumulatively, the number of commissive statements is more than the other Investigating Aspects Affecting Joe Biden's Speech (Triana, Y., Zulaiha, D.) 
statements. This indicates that there are so many visions of the president of the United States, because he talks about reform and change of government.

\section{Verbal act}

Direct performance of the speaker is also found in the speech. The following are two statements dealing with verbal act spoken by Biden.

\section{Table.5 UtTERANCE RELATED TO VERBAL ACTS}

\begin{tabular}{|l|l|}
\hline \multicolumn{1}{|c|}{ Illocutionary Force } & \multicolumn{1}{|c|}{ General Intention } \\
\hline $\begin{array}{l}\text {...and I ask every American to join me in this cause } \\
\text { uniting to fight the foes we face anger resentment } \\
\text { and hatred extremism lawlessness violence } \\
\text { disease joblessness and hopelessness. }\end{array}$ & Biden asks Americans to join him. \\
\hline $\begin{array}{l}\text { so I ask you let's say a silent prayer for those } \\
\text { who've lost their lives and those left behind and } \\
\text { for our country, amen folks }\end{array}$ & Biden also ask people to say in a silent prayer. \\
\hline
\end{tabular}

Above are two statements that can be interpreted the same as an illocutionary act. The first sentence is a request sentence. Specifically, Biden called on Americans of all backgrounds to join forces against legal and economic injustice. In the second sentence, Biden asks directly and together to pray for America and the Americans who have died.

\section{DISCUSSION}

Political discourse analysis is a critical discourse analysis which also examines the power of politics. It needs to specify political discourse into critical discourse to get the intention of the speaker (Van Dijk, 1997). The present study refers to the reproduction of political power or domination and any close relationship with them. It could have a link with new cross-discipline. Political power can be seen from the political position of people in a community and the community it shelters (Dunmire, 2018). In addition, politics is also closely related to social, economic, and cultural aspects (Luke, 2002). Explicitly, political discourse discusses three main units of political dimensions: the president, the formal political unit, and the community. The political phenomenon may be discussed deeply and completely until the phenomenon has little or no relation to an object or discipline. Figure 1 below explains the position of a president represents as an actor of a speech. He also represents a person in political power over constitutional communities. 


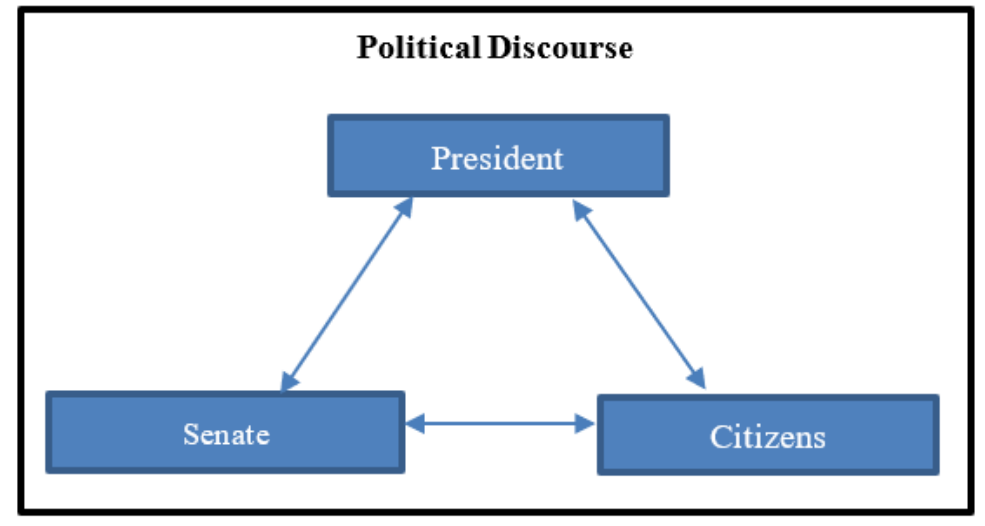

Figure 1. Political Dimension of the Speaker

In discourse analysis, at least some realities has been built (Gee, 2001). The picture above shows that each unit is closely related and has authority. Take for instance, the senate can be an actor to influence the president and also a civilian. In a presidential speech, the president is a political actor in which his political policies will definitely relate to other political institutions such as the senate in the house of representatives, Capitol Building. The president's policy will be directly related to the economic, social and cultural life of the community. As a state official, the president has the political power to invite and control, even dominate. What a national figure says will certainly have an impact on society, especially the president of the United States. Official presidential speeches tend to be related to politics because the president is a political figure from a political party. Researchers looked for a potential review of Biden's official statement by linking the information found in relevant documents. However, the researcher only focuses on the aspects behind Biden's speech. According to experts, there are five aspects that influence a speaker to speak (Leech, 1983). Biden as the speaker of the speech is the political actor who also has the following factors:

\section{Addressers and Addressees}

The President of the United States of America is the state head with the authority to lead the US armed force. Taken from the official website of the White House, the President is responsible for implementing and enforcing the laws written by the Congress and, to that end, appoints the heads of the federal agencies, including the Cabinet. Besides, the president has the power to make or veto bills passed by the Congress, although the Congress can overturn the veto by two-thirds of the vote from both houses. The President also has the power to negotiate and sign treaties ratified by the Senate. The role of the president is closely related to the position of the US as a world power. According to the recent CIA World Factbook, America has economic, military, and cultural influence. Further, it has significant contribution to the United Nations founding, become 
dominant country on NATO, and many others. In other words, the president is an addresser who has a superpower position in the US and internationally. The president is also a leading role in international institutions as the UN and NATO. The data illustrates the identity of a speaker that he has special circumstances. that situation will affect the meaning of language, activity, relations, politics and connections (Gee, 2001).

Addressees were spoken clearly and explicitly, but there is addressee that is spoken implicitly. It is a product of consequential effects created by speaker to deliver intention (Tiersma \& Geis, 1998). Hearer needs feelings and thoughts to understand the purpose. So, it is found that there are two kinds of addressees based on how the addresser expresses: the explicit and implicit addressee. An explicit addressee is used to mark someone's social or political status (Shalihah, 2019). Moreover, the use of address depends on the relationship between speaker and hearer. It is explained that address indicates the purpose and the situation of the conversation, the interlocutors" age, social status, social relationship, sex, profession, marital status, politeness and other related aspects (Susanto, 2014). Similarly, Joe Biden addressed his message clearly to his colleague in Democrats. Speaker Nancy Pelocy was called clearly and straightforwardly at the beginning of the speech. It means that the speaker of the house of representatives is the leader of house of representative and the person who contributed to Biden's victory.

\section{The context of speaker}

In a general context, the president certainly deals with all aspects of the state. This is because the president is the superpower identity capable of changing and influencing various circumstances in the country and the world. In particular, language is interpreted as a specific context. Context will be related to particular meaning, then language will be easy to break down (Indrawati, 2009). More specifically, Biden spoke of the president's responsibility to the latest problems facing America. This is in line with the top priorities posted on the official Whitehouse web page, https://www.whitehouse.gov/priorities/. It shows that the Biden government is focused and serious on issues that are at the center of public attention. There are several serious problems that will be resolved by the president.

On health issues, the government will ensure fair health services for all levels of society. He said, "We can reward work and rebuild the middle class and make health care secure for all". This problem cannot be separated from the conditions faced by America in fighting the Covid-19. There are at least thirty million more cases of covid-19 and among them half a million Americans died. Taken from https://www.worldometers.info/coronavirus/, this figure continues to increase and has not decreased significantly. 
On economic issues, the government will rebuild the US economy during the covid-19 crisis. The president stated that covid-19 made many businesses closed and many people have been jobless. The small business revenue has been down, bankruptcies have increased, layoffs and shutdowns have also increased (Bauer et al., 2020). That fact made the president pledge to recover the state of the economy in the United States. Moreover, he specifically said that the American people would have good jobs.

It was also reported that the shutdown of education sectors during the covid-19 made many students study at home (Bauer et al., 2020). Mr. President said that they would be in safe schools. In 2021, the agency's National Threat Assessment Center (NTAC) reported an analysis of 67 plots to attack K-12 schools and averted 2006 to 2018 (Alathari et al., 2021). There was a significant increase in cases of violence occurring in schools. The context of this situation is also likely to be of concern to the elected president, Joe Biden. The government ensures safety for students and educators in schools.

The president said that his administration would defeat political extremism and domestic terrorism on politics, social, and culture issues. This remark is closely related to the riots that occurred at the Capitol Building. The deaths of five Capitol Building people are closely related to elections in the United States. This is a series of American elections won by the elected president, Joe Biden. After the announcement of the victory, Donald Trump's supporters came to the Capitol building and rioted. The pro-Trump rioters fought the officers, so the officers shot the rioters (Healy, 2021).

Further, Joe Biden also said "This is a time of testing we face an attack under democracy and on truth a raging virus growing inequity the sting of systemic racism a climate in crisis". He aimed to speak out against American democracy which was damaged when the people of the United States were hit by the Covid-19 crisis. In fact, Joe Biden accused actors who intervened in the riots at the Capitol Building. He adds "Politics doesn't have to be a raging fire destroying everything in his path every disagreement doesn't have to be a cause for total war and we must reject the culture in which facts themselves are manipulated and even manufactured".

Biden's speech is closely related to the situation and conditions that occur in the United States and the world. Specifically, Biden's political speech deals with the US democracy, the COVID-19 pandemic, the impact of pandemic, and politics. Of course, the finding is in line with previous research (Darong, 2021), mentioning that upon a problem that occurs, Joe Biden offers a solution to it. This is to get listeners to support the new American administration program. This paper is in line with a previous study by Akinkurolere (2019), stating that two physical contexts influence the president's state speech: discourse context, i.e., word information physical social context, i.e., the experience of the speaker and physical environment. 


\section{The goal of the speaker}

The relationship between speaker and hearer is the speaker's point to deliver a particular goal (Tiersma \& Geis, 1998). Joe Biden as a president certainly has potential relation withvarious parties because he has the power to affect the hearers; in this case, society. In Joe Biden's official speech, the president made several statements that were closely related to American society. He plans to make changes to political action, allowing. a better condition of American society than the previous administration. The Biden government will enforce a democracy that was manipulated. This is as expressed by Biden as follows:

We can do this if we open our souls instead of hardening our hearts, if we show a little tolerance and humility, and if we're willing to stand in the other person's shoes - as my mom would say, Just for a moment, stand in their shoes...

Biden also emphasized the sentence above explicitly using the following statement.

We face an attack on our democracy and the truth...

Above is the state of democracy in the United States where the attack some time ago on the Capitol building killed several rioters. It is a form of resistance to democracy. The statement is also a political action against intolerance and radical racism. In fact, Biden will also fight against this virus just like against the Covid-19 virus in the United States by expressing the following sentence.

This is a time of testing we face an attack under democracy and on truth a raging virus growing inequity the sting of systemic racism a climate in crisis.

For a message to the world, Biden called for making political changes by evaluating existing policies.

"We will repair our alliances and engage with the world once again - not to meet yesterday's challenges, but today's and tomorrow's challenges.

Biden's statement above is almost the same as the Washington Post journalist's analysis that Joe Biden stated four important goals, ranging from resistance against "uncivil war" up to political messages to the United States Alliance. According to Blake (2021), there are four points presented by Biden on the inauguration, i.e., the 'uncivil war' plaguing our country, a marked contrast to Trump's inaugural, a call for 'boldness' from a pragmatist, and a message to other countries.

\section{Speech act}

Speech act theory explained that utterance has three distinctive acts. According Levinson, speech act can express locutionary act, illocutionary act, and perlocutionary act (Levinson, 1980). According to Searle's illocutionary act, there are some classifications of act like assertive, 
directives, commissive, expressive and declaratives (Searle, 1979). Here, utterances were presented in two classification including speech act classification and illocutionary acts.

Speech acts can describe various backgrounds, both situations and speakers and even listeners. Recent studies show that the speech act by Joe Biden describes the personality of a president (Ahmed \& Amir, 2021). It showed that the president mostly used the directive, representative, and commissive speech act. However, speech act in a political situation describes the speaker's personality and other aspects such as the current political situation, political opponents, and listeners.

Joe Biden's state speech could not be separated from the political context in the United States. This can be identified from the purpose of the speech message. The speech was addressed to political opponents, namely the Republican party by placing Donald Trump at the center of attention. The defeat of political opponents caused Donald Trump's supporters to riot in the Capitol Building. The unrest is considered the current political democratic situation in the United States. In addition, the Covid-19 outbreak that spreads in the country also describes various crisis situations related to political policies to economic situations. Hence, viewed from the aspect of Joe Biden's personality, the current political situation and the current state of listeners (the people of the United States) implies a political promise that will be carried out during his reign.

Speech in political discourse always describes the intention of the speaker (Akinkurolere, 2019), because speakers, context, and listeners are closely related to each other. Joe Biden's state speech can be said to have had various intentions. The speech was a move by Joe Biden to convince to listeners that his government is better than the previous one. The speaker also convinced the listeners about the government's strategic program in an effort to solve all problems in America.

\section{Verbal act}

A verbal act is also an illocutionary force that provides an explicit explanation and meaning. Illocutionary force is an illocutionary act that is interpreted according to the appropriate usage (Levinson, 1980). It is simple to understand because the illocutionary force has the same structure and meaning as the locutionary act. The verbal act can be seen from the use of the speech act used by the speaker (Lindayana et al., 2018). The characteristic is that speakers usually use directive speech, such as commanding and asking. In line with Ahmed \& Amir (2021), it is stated that the verbal act is indicated by the presence of a direct speech act. In Joe Biden's state address, the direct speech act was mostly used. This shows that all groups, both within and outside the country, understand the president's speech very easily. A speech with a large amount of indirect speech content creates multiple interpretations. Indirect speech requires knowledge of the context of a deep social-political situation. 
The command that a president calls out is a direct invitation to listeners. The invitation should be clear without any implicit words. The explicit word will make it easier for listeners to understand the exclamation directly without thinking hard. Joe Biden asks all members of the community to support the new government to build a strong government.

\section{CONCLUSION}

Looking at the theory of Leech, findings on Biden's statements qualify its aspects of speech. It means that his official political statements address political society in a particular situation. There is a close relationship between both political members and the socio-political situation. The purpose can be indirect or direct depending on the particular intention that is being discussed. It is clear but it is stated using locutionary acts that need to be interpreted using contextual analysis. This denotes specifically a study of political discourse analysis. Biden's inaugural speech presented recent socio-political condition in America that experienced setbacks. Then, he offered American and Alliances to trust him because he wants to fix deterioration and fix international cooperation. Furthermore, illocutionary act of utterance in political discourse analysis does not only need aspects of speech to interpret but it also needs wide political knowledge and philosophy. Hopefully, there is a further study discussing the tendency of the pragmatic aspects of language spoken by Joe Biden. Moreover, these researchers are American pragmatic linguists who focus on researching political discourse.

\section{REFERENCES}

Ahmed, H. R., \& Amir, S. (2021). Speech Act Analysis of the Joseph R . Biden , Jr .' s Inaugural Address on 20th of January 2021 as the 46th President of the USA. Electronic Research Journal of Social Sciences and Humanities, 3(February), 43-55.

Akinkurolere, S. (2019). Exploring the Significance of Context in Meaning: Speech Act Features of Performative Political-Speeches of President Umaru Musa Yar'Adua. Athens Journal of Humanities \& Arts, 7(1), 65-84. https://doi.org/10.30958/ajha.7-1-3

Alathari, L., Drysdale, D., Carlock, A., Cotkin, A., Johnston, B., Driscoll, S., Mauldin, D., McGarry, J., Nemet, J., \& Vineyard, N. (2021). Averting Targeted School Violence.

Austin, J. L. (2011). How To Do Things With Words. In How To Do Things With Words. https://doi.org/10.1093/acprof:oso/9780198245537.001.0001

Bauer, L., Broady, K., Edelberg, W., \& Donnell, J. O. (2020). Ten Facts about COVID-19 and the U . S . Economy. The Hamilton Project, Brookings Papers, September.

Beckley, M. (2018). The power of nations: Measuring what matters. International Security. https://doi.org/10.1162/ISEC_a_00328

Blake, A. (2021). 4 takeaways from Joe Biden's inaugural address. Washington. The Washington Post. https://www.washingtonpost.com/politics/2021/01/20/takeaway-biden-harrisinauguration/. 
Darong, H. C. (2021). Interpersonal Function of Joe Biden 's Victory Speech ( Systemic Functional Linguistics View ). Journal of Educational Research and Evaluation, 5(1), 57-66.

Dunmire, P. L. (2018). Political Discourse Analysis : Exploring the Language of Politics and the Politics of Language Political Discourse Analysis : Exploring the Language of Politics and the Politics of Language. July. https://doi.org/10.1002/lnc3.365

Fairclough, N. (2013). Critical discourse analysis. In The Routledge Handbook of Discourse Analysis. https://doi.org/10.4324/9780203809068-8

Gee, J. P. (2001). An Introduction to Discourse Analysis: Theory and Method. In An Introduction to Discourse Analysis. Routledge. https://doi.org/10.4324/9781315835884

Healy, J. (2021). These Are the 5 People Who Died in the Capitol Riot. The New York Times. https://www.nytimes.com/2021/01/11/us/who-died-in-capitol-building-attack.html

Indrawati. (2009). Context in Pragmatics. Language Circle: Journal of Language and Literature, 3(2), 23-31. https://doi.org/10.15294/lc.v3i2.916

Kameswari, L., \& Mamidi, R. (2018). Political discourse analysis : a case study of 2014 andhra pradesh state assembly election of interpersonal speech choices. Proceedings of the 32nd Pacific Asia Conference on Language, Information and Computation, PACLIC 2018, December, 239-246.

Leech, G. N. (1983). Principles of Pragmatics (First Edit). Longman Group Limited.

Levinson, S. C. (1980). Survey Article: Speech Act Theory: The State of the Art. In Language Teaching. https://doi.org/10.1017/S0261444800008661

Lindayana, L., Arifuddin, A., \& Mandala, H. (2018). Politeness of Verbal and Non-Verbal Directive Speech Acts in the Tenth Grade Students' Learning Process of Negeri 1 Mataram. RETORIKA: Jurnal Ilmu Bahasa, 4(1), 70-74. https://doi.org/10.22225/jr.4.1.526.70-74

Luke, A. (2002). Beyond Science and Ideology Critique: Developments in Critical Discourse Analysis. Annual Review of Applied Linguistics. https://doi.org/10.1017/s0267190502000053

Rachman, A., Yunianti, S., \& Ratnadewi, D. (2017). Critical Discourse Analysis in Donald Trump Presidential Campaign To Win American'S Heart. TELL Journal, 5(2), 8-17.

Searle, J. R. (1979). Expression and Meaning: Studies in the Theory of Speech Acts. Cambridge University Press. https://doi.org/doi:10.1017/CB09780511609213

Shalihah, M. (2019). A Pragmatic Analysis on The Types and The Purposes of Address Terms Used by the Main Character in Jane Austen ' s "EMMA." EnJourMe (English Journal of Merdeka) : Culture, Language, and Teaching of English, 3(2), 52-60. https://doi.org/10.26905/enjourme.v2i2.2747

Susanto, D. (2014). The Pragmatic Meanings of Address Terms Sampeyan and Anda. Indonesian Journal of Applied Linguistics, 4(1), 140-155. https://doi.org/10.17509/ijal.v4i1.606

Tiersma, P., \& Geis, M. L. (1998). Speech Acts and Conversational Interaction. Language. https://doi.org/10.2307/417570

Triana, Y., Sari, I. F., \& Apriyanto, S. (2020). Language Features and Causes of Suicide Case from Forensic Linguistics Point of View. International Journal of Psychosocial Rehabilitation, 24(6). https://www.psychosocial.com/article/PR260803/19450/

Van Dijk, T. A. (1997). What is Political Discourse Analysis? Belgian Journal of Linguistics, 11, 1152. https://doi.org/10.1075/bjl.11.03dij

Waisanen, D. J., \& Becker, A. B. (2015). The Problem with Being Joe Biden : Political Comedy and Circulating Personae The Problem with Being Joe Biden : Political Comedy and Circulating 
Personae. September. https://doi.org/10.1080/15295036.2015.1057516

Wall, J. D., Stahl, B. C., \& Salam, A. F. (2015). Critical discourse analysis as a review methodology: An empirical example. Communications of the Association for Information Systems, 37, 257-285. https://doi.org/10.17705/1cais.03711

\section{Official Data Source}

https://www.youtube.com/watch?v=q5iCPKDp4V4

https://www.washingtonpost.com/politics/2021/01/20/takeaway-biden-harris-inauguration/

https://www.whitehouse.gov/about-the-white-house/our-government/the-executive-branch/

https://www.cia.gov/the-world-factbook/countries/united-states/ 